\title{
Mapping the Seafloor Geology Offshore of Massachusetts
}

\section{Introduction}

Geologic and bathymetric maps help us understand the evolutionary history of the Massachusetts coast and the processes that have shaped it. The maps show the distribution of bottom types (for example, bedrock, gravel, sand, mud) and water depths over large areas of the seafloor. In turn, these two fundamental parameters largely determine the species of flora and fauna that inhabit a particular area. Knowledge of bottom types and water depths provides a framework for mapping benthic habitats and managing marine resources. The need for coastal-zone mapping to inform policy and management is widely recognized as critical for mitigating hazards, creating resource inventories, and tracking environmental changes (National Research Council, 2004; U.S. Commission on Ocean Policy, 2004).

\section{A State-Federal Cooperative Mapping Project}

Geologic mapping of the Massachusetts inner continental shelf is a cooperative effort by the U.S. Geological Survey (USGS), the Massachusetts Office of Coastal Zone Management (CZM), and the National Oceanic and Atmospheric Administration (NOAA). Priority areas are identified through consultation with State and local partners, NOAA contributes data originally collected to update navigation charts, and the USGS provides technological capabilities and science expertise. The overall project goal is to map the geologic framework of the region inside the 3-mile limit of State waters. The mapping builds on long-term USGS studies of Massachusetts Bay and Boston Harbor (Butman and others, 2004) that enhance our ability to 1) predict coastal change due to erosion, storms, and sea-level rise; 2) assess sand and gravel resources on the inner shelf, and 3) develop geospatial information relevant to habitat identification. The comprehensive mapping approach used in this study supports efforts by the State to manage ocean resources and provides a procedural model for other states who wish to address similar resource-management needs.

The mapping project began in 2003 in the area between Nahant and Gloucester (area 1) and in Boston Harbor (area 2). The project expanded in 2005 to the inner shelf north of Cape Ann (area 3), an environmentally important area offshore of Plum Island, the largest barrier-island system in New England. In the summer of 2006, the program will be extended to newpriority areas southeast of Boston (area 4) and in western Cape Cod Bay (area 5). All areas are shown on fig. 1.

The purpose of this fact sheet is to demonstrate the utility of seafloor maps for scientific research and ocean-resource management. First, we summarize the geologic setting of the Massachusetts coastal zone, and then describe the tools and techniques used to produce the maps. Finally, we show how the large amounts of data collected from area 1 were compiled within a geographic information system (GIS) to generate interpretive mapping products.

\section{Geologic Setting}

The coast and inner continental shelf of northeastern Massachusetts are bedrock framed with numerous islands, shoals, and rugged headlands. The seafloor is covered with a wide variety of materials whose characteristics are dictated by the inherited geologic framework, multiple glaciations, and changes in relative sea level (Schlee, 1973). The hard, erosion-resistant bedrock in the vicinity of Cape Ann mostly consists of complexly faulted granite and basalt that range in age from about 250 to 540 million years (Zen and others, 1983). Glaciers have repeatedly advanced across the landscape during the last 1.8 million years, and have scoured the craggy Cape Ann peninsula and deposited the eroded detritus on the adjacent seafloor. Since the end of the last Ice Age, sea-level changes have driven lateral migrations in the position of the coastline and made it

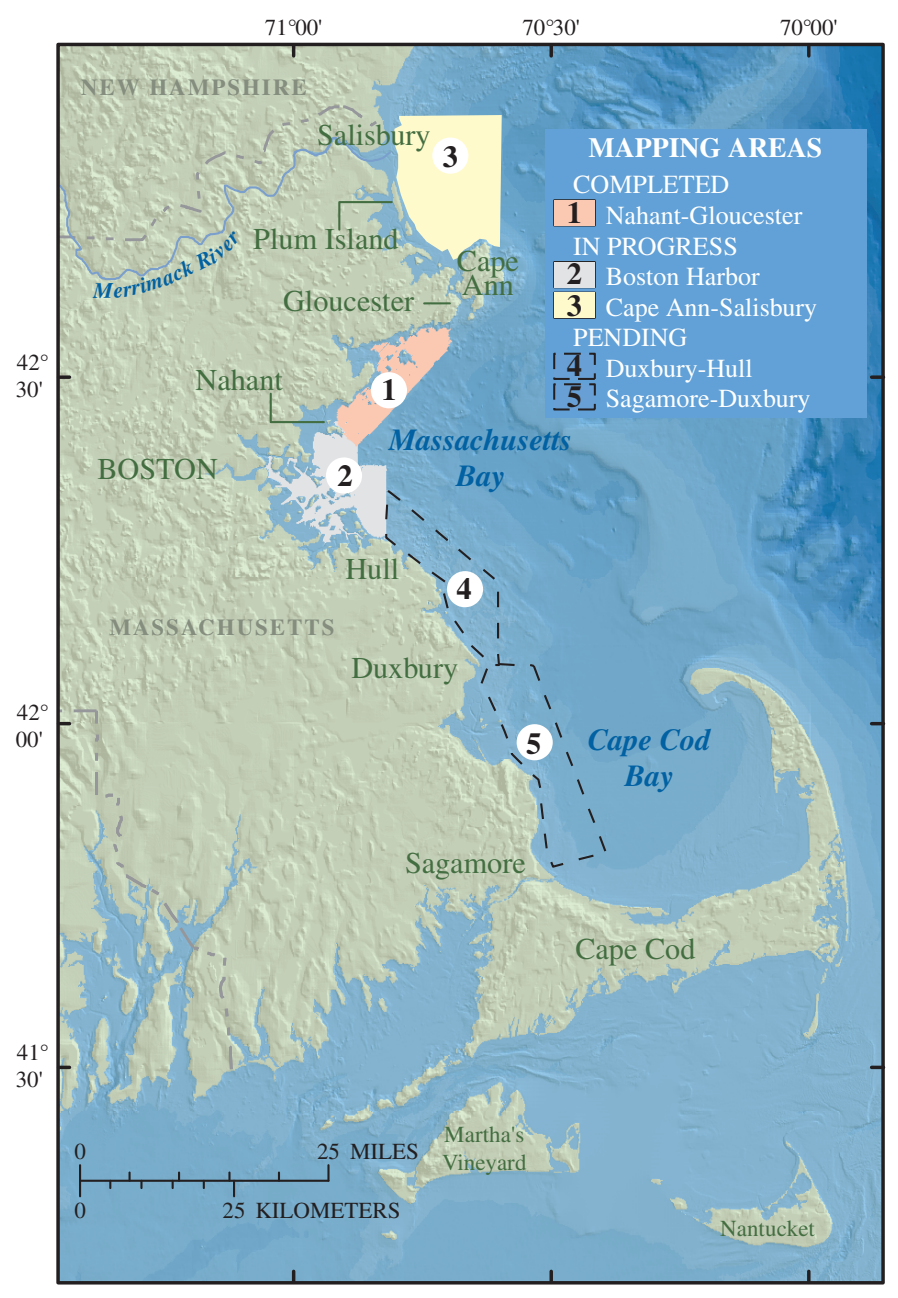

Figure 1. Map showing the five areas of seafloor mapping in Massachusetts. 
possible for waves and currents to shape wide areas of the inner shelf. Erosion of older glacial deposits on the coast and inner shelf has produced sand that has built local beaches and muddy sediment that has accumulated in small estuaries. Removal of the fine-grained sand and mud by ocean processes has left behind extensive deposits of bedrock, gravel and boulders in exposed areas along and seaward of the outer coast.

\section{Geologic Characterization of the Seafloor}

Mapping the geology in this formerly glaciated region is difficult because 1) the rugged, high-relief seafloor exhibits abrupt changes in water depth, and 2) different substrates form a distinct patchiness on the seafloor that changes over distances of only a few meters. For example, high-relief bedrock and boulder deposits are commonly exposed on the seafloor in close proximity to flat-lying deposits of sand and mud. Rocky areas also contain isolated accumulations of shell sediment in small cracks and other low-lying areas between outcrops. These small-scale variations present a great challenge to marine geologists, who need to map complex geologic environments in a format that is useful to managers and policy makers.

The first map for this project was completed in 2005 for area 1 (fig. 1), and the resulting data and maps were published online (Barnhardt and others, 2005). The map encompassed 134 square kilometers (52 square miles) of the inner shelf with a focus on the nearshore region, which has water depths of 5 to 40 meters (16 to 132 feet). Three seafloor-mapping systems were used to examine the geologic framework in three dimensions: bathymetric sonar, sidescan sonar, and subbottom profiling. These systems transmit acoustic waves (sound) from a research vessel and record the waves reflected from the seafloor back to the ship. The acoustic data provided detailed information on

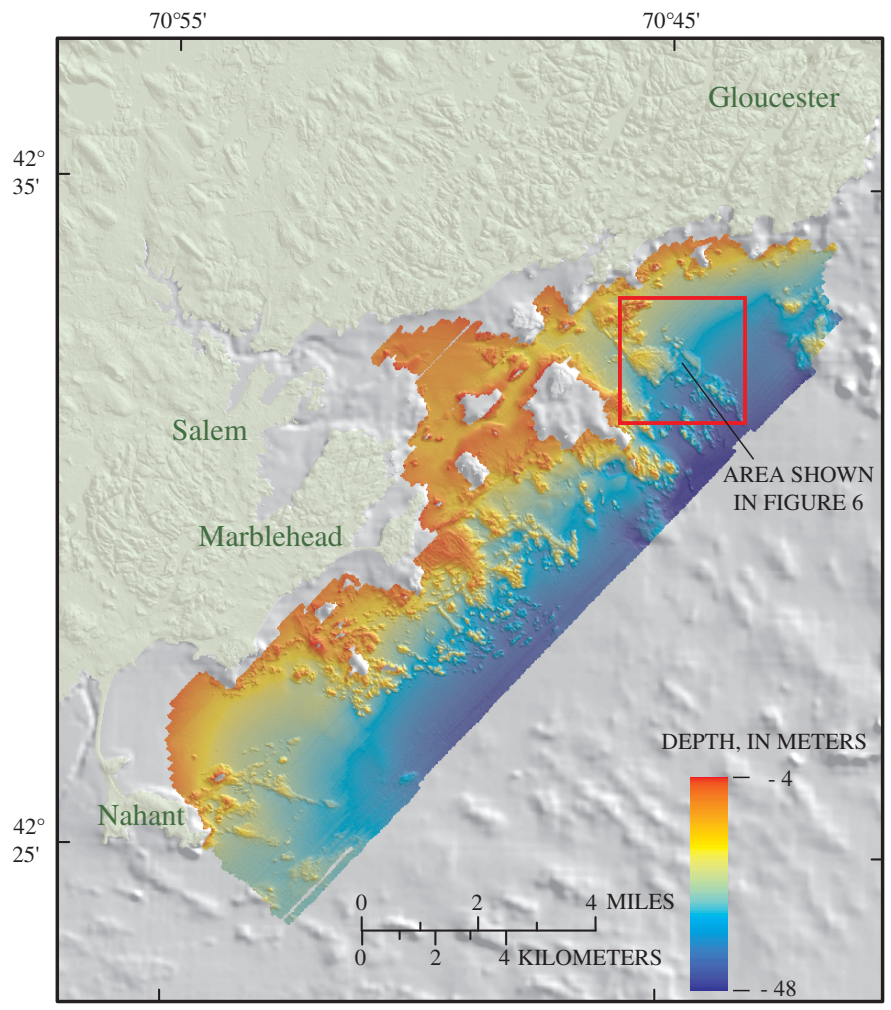

Figure 2. Map of seafloor topography. Bathymetric sonar collects soundings of water depth in a wide swath beneath the ship. Depth is color-coded with reds and oranges indicating shallow water, and blues and greens indicating deeper water. These data show the detailed shape of the seafloor, resolving high-relief, bouldery deposits such as moraines and drumlins formed by glaciers that scoured the region during the last Ice Age. The box indicates the location of data layers shown in figure 6 .

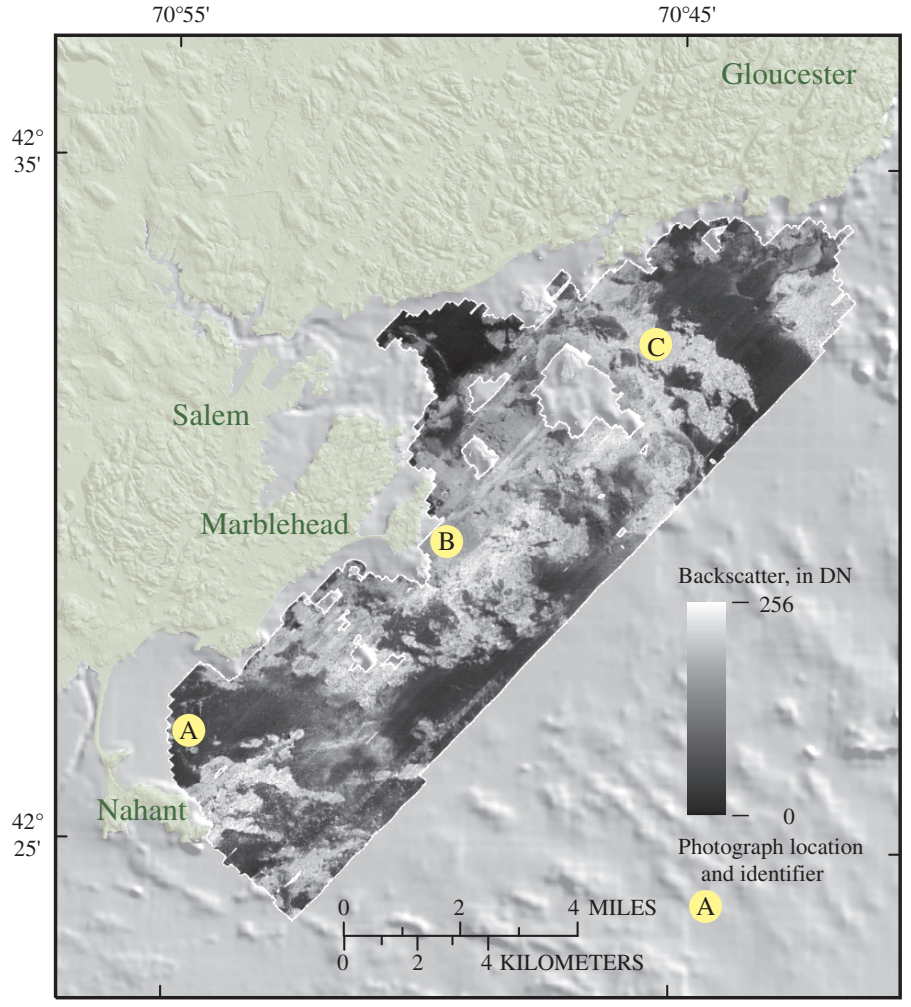

Figure 3. Backscatter image of seafloor, produced with sidescan sonar. Backscatter values within this image indicate the strength of sound waves reflected off the seafloor and are represented by digital numbers (DN) that range from 0 to 256 . High backscatter (light tones) is associated with generally coarse sediment and rock outcrops. Low backscatter (dark tones) is associated with generally fine-grained mud and fine sand. Broad areas of dark-toned, finer sediment correlate with areas of smooth topography in figure 2; light-toned rocky areas correlate with areas of high-relief topography. Yellow circles indicate the locations of three photographs shown in figure $5 \mathrm{~A}-\mathrm{C}$.

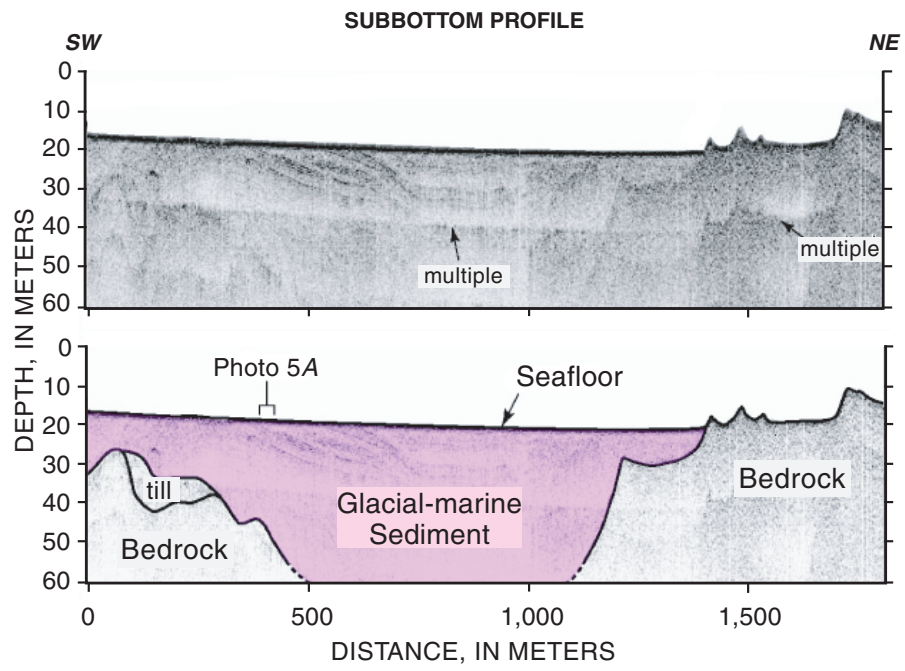

Subbottom Profile. The upper diagram is the original data and the lower diagram is an interpreted section showing the geometry and thickness of sediment deposits that lie at or beneath the seafloor. The vertical axis represents the depth below the sea surface, and the horizontal axis the distance traveled while collecting these data. Arrows labeled "multiple" indicate artifacts in the data, not actual layers. A subbottom profile is analogous to a slice of cake, showing the layered internal structure of materials that compose the seafloor. The profile crosses a bedrock-framed valley filled with thick glacial-marine sediment (pink), which is locally exposed on the seafloor (photo in figure $5 A$ ). Surficial sediment is thin to absent on the right side of the profile, where bedrock is exposed at the surface. This profile is represented by the black line in figure 4 . 


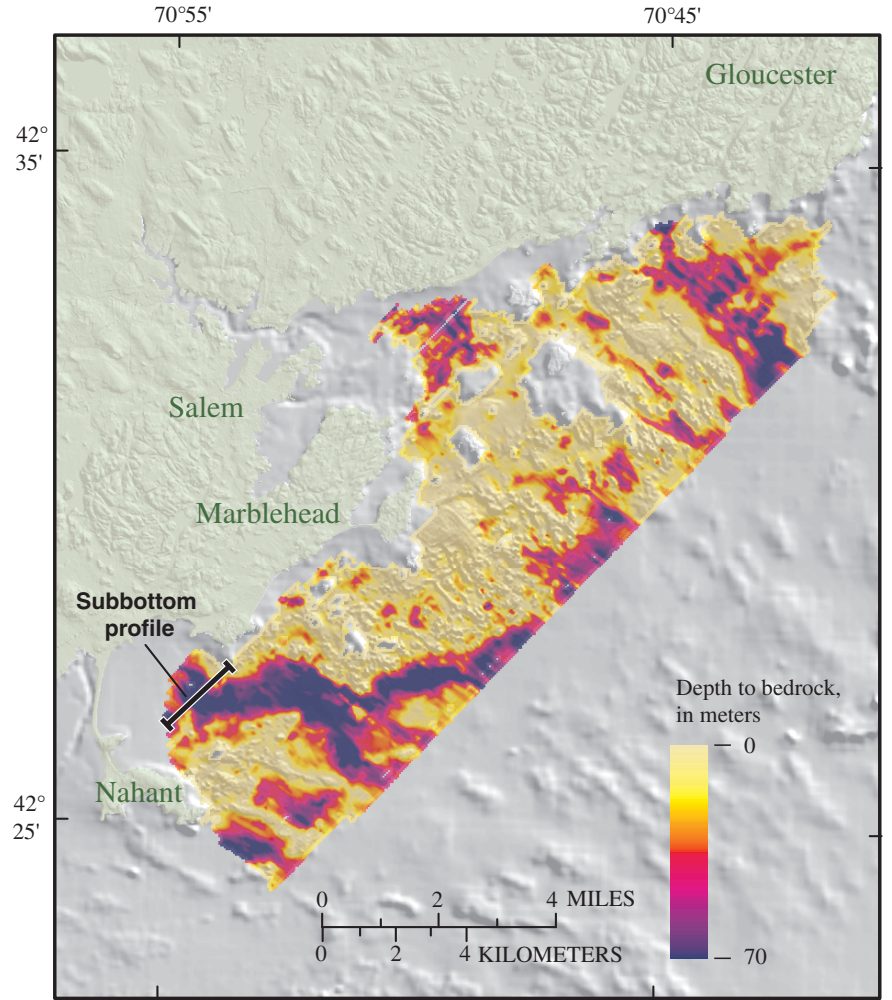

Figure 4. Map of sediment thickness. A subbottom profiler provides information on the thickness and origin of sediment deposits. The map is based on a closely spaced grid of data produced by a series of subbottom profiles like that in the SW-NE profile shown on the previous page. Yellow tones represent thin or absent sediment cover; purple tones represent relatively thick sediment. The elongate purple feature (lower left) represents thick sediment deposits filling a bedrock valley.

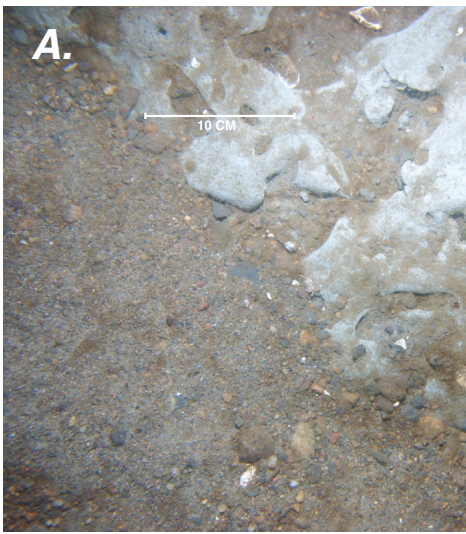

Figure 5.

Photographs of the

seafloor. $A$, A thin, discontinuous

sheet of sand partially buries underlying

deposits of blue-gray, cohesive clay (glacia

marine sediment). The sand is associated with areas of low

backscatter in figure 3. $B$, Sand and gravel with shell fragments derived

from calcareous organisms that live on adjacent areas of hard substrate. Sand

and gravel is associated with areas of moderate to high backscatter in figure 3. $C$, Cobbles

and boulders encrusted with coralline algae, barnacles, and mussels are associated with areas of

high backscatter in figure 3 . Crevices provide shelter for lobsters and other organisms.

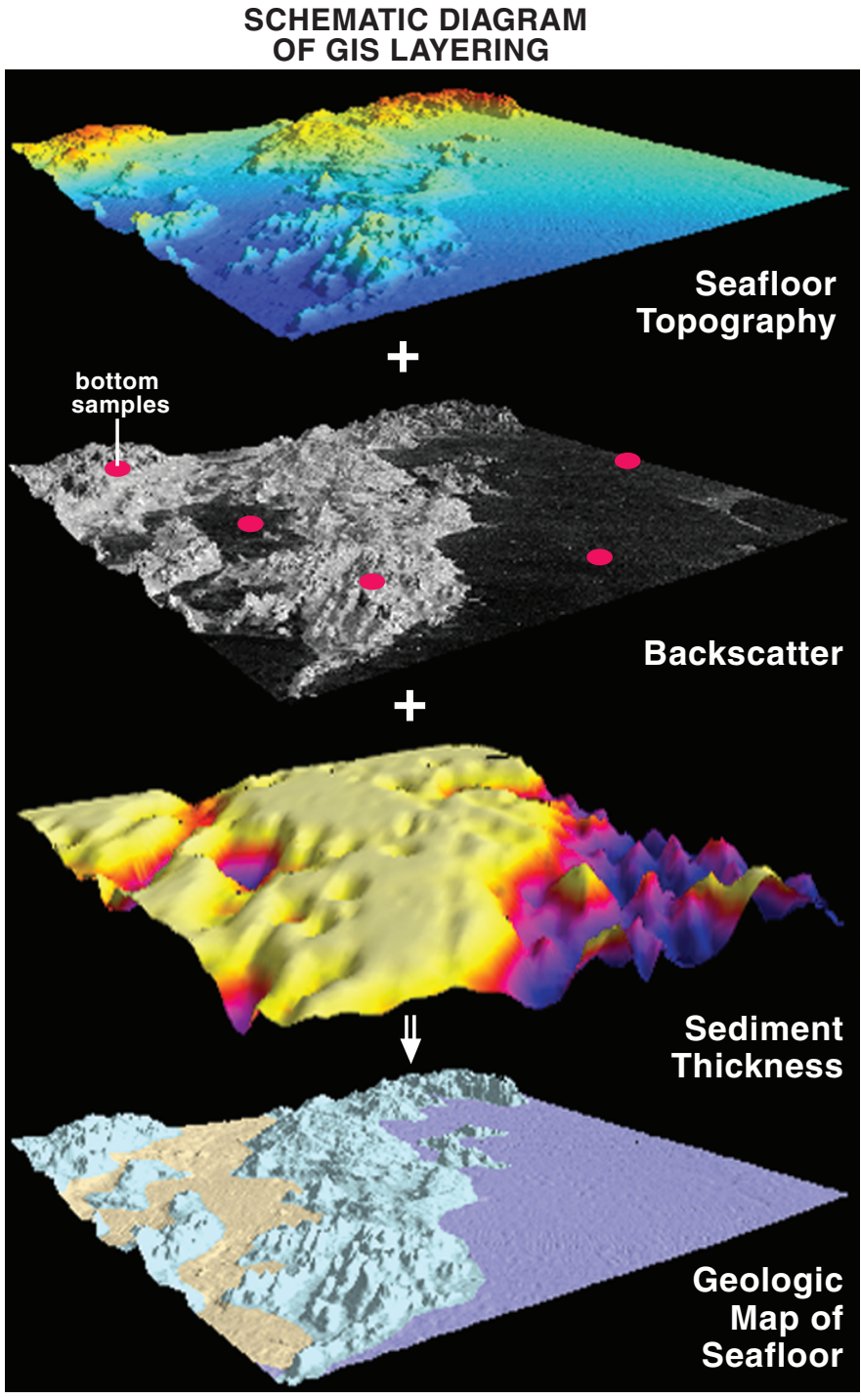

Figure 6. Data layers within a geographic information system, from top to bottom: seafloor topography, backscatter and bottom samples, sediment thickness, and interpretive geologic map. The top three layers and other derived data such as seafloor slope were compiled to support the regional interpretation of seafloor geology (bottom layer) that appears in figure 7. 


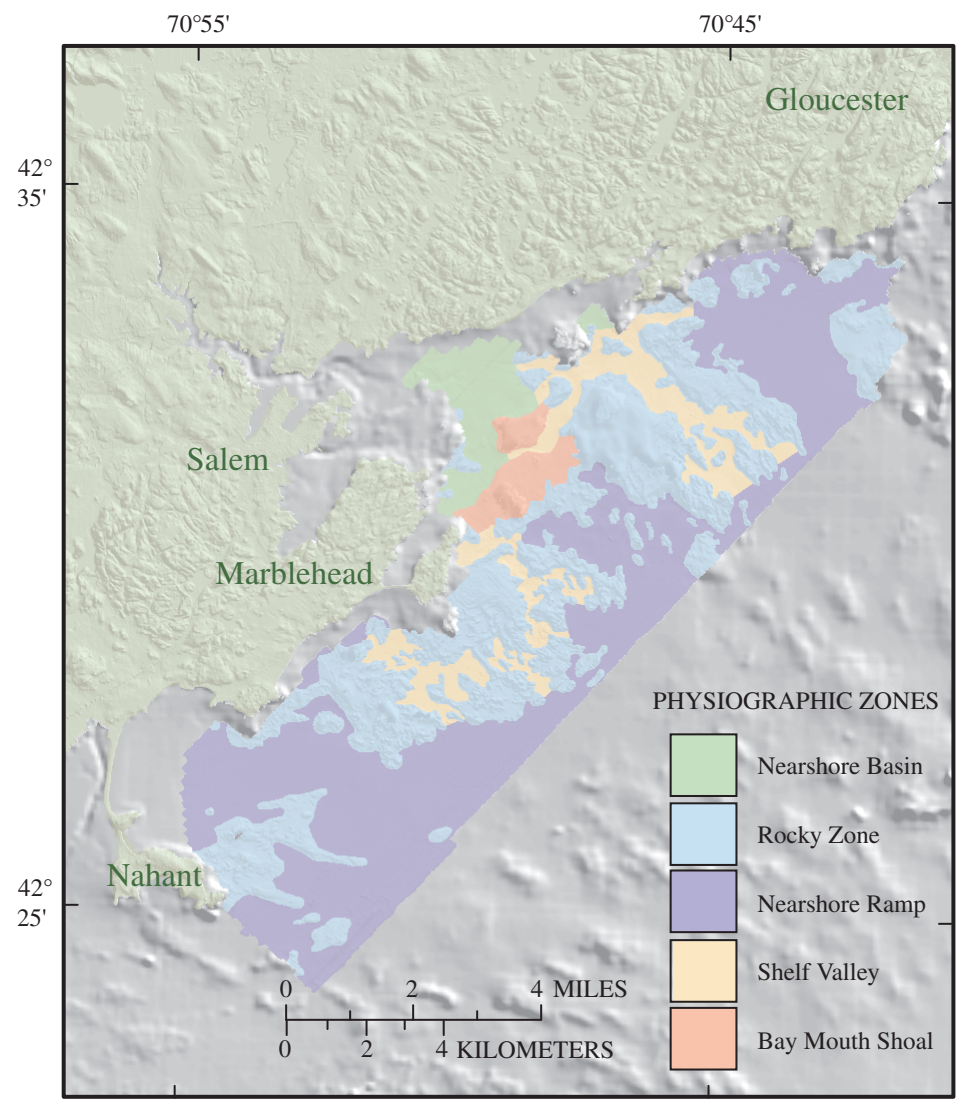

1. Nearshore Basin

- smooth, flat-lying areas; thick muddy sediment

- sheltered areas within embayments

- cover $7.0 \mathrm{~km}^{2}$ (2.7 $\mathrm{mi}^{2}, 5.3$ percent) of map area

\section{Rocky Zone}

- high-relief rock outcrops, boulders and gravel

- exposed areas along open-ocean coast

- cover $52.4 \mathrm{~km}^{2}$ (20.2 mi $\mathrm{mi}^{2}, 39.2$ percent) of map area

\section{Nearshore Ramp}

- smoothly seaward-sloping areas; generally sandy sediment

- extend offshore from coast to depths greater than 40 meters

- cover $57.3 \mathrm{~km}^{2}\left(22.1 \mathrm{mi}^{2}, 42.9\right.$ percent $)$ of map area

\section{Shelf Valley}

- elongate valleys and interconnected depressions partially filled with sediment

- extend offshore, perpendicular to coast

- cover $12.5 \mathrm{~km}^{2}$ (4.8 $\mathrm{mi}^{2}, 9.3$ percent) of map area

\section{Bay Mouth Shoal}

- flat-topped banks of sand and gravel

- reworked by waves and tides at mouths of embayments

- cover $4.4 \mathrm{~km}^{2}$ (1.7 $\mathrm{mi}^{2}, 3.2$ percent) of map area

Figure 7. Geologic map of seafloor for area 1. Five environments, or physiographic zones, are delineated on the basis of the data from seafloor-mapping systems and sampling presented in figures 2-5. These geologic environments are described in the table at right. [ $\mathrm{km}^{2}$, square kilometers; mi², square miles]

seafloor topography (fig. 2), the type and distribution of seafloor sediments (fig. 3), and thickness of sediment deposits (fig. 4). The imagery derived from seafloor-mapping systems was validated by sediment sampling and photography (fig. 5). The different data types were integrated as a series of layers within a GIS (fig. 6) to produce interpretations of seafloor geology.

The final product, an interpretive geologic map (fig. 7), synthesized the complex geology at a regional scale and made the information available to both scientific and nontechnical audiences. For regional mapping purposes, we defined five map units or physiographic zones, which are summarized below. The zones are based on seafloor topography, the dominant bottom types present, and the thickness of sediment deposits. Although considerable variation in these characteristics exists within each zone, this method allows efficient mapping of large areas and presents geologic information in a readily useable format.

\section{Seafloor Mapping Supports Informed Decision Making}

As coastal communities expand in population, pressure also grows to develop energy, transportation, and other infrastructure in the shallow ocean adjacent to our coasts. Generating accurate maps of seafloor geology in these sensitive areas is an important first step toward protecting fish habitat, delineating marine reserves, and assessing environmental changes. The USGS/CZM/NOAA cooperative project represents part of a two-phase, multidisciplinary approach to research on the structure and function of marine habitats. The first phase, described in this fact sheet, seeks to gain an understanding of the geologic framework in the study area and communicate that information to scientists, industry, and the public. The second phase, which is just beginning, will use the defined geologic framework to guide biological sampling. For example, the Massachusetts Department of Marine Fisheries already uses the maps and data layers produced for area 1 to monitor the recovery of marine habitats disturbed by construction of a submarine pipeline. The ultimate goal is to merge the regional geologic mapping with site-specific biological assessments, thereby fully characterizing benthic habitats and providing guidance for policy decisions that affect coastal and nearshore environments.

\section{References}

Barnhardt, W.A., Andrews, B.D. and Butman, Bradford, 2005, High-resolution geologic mapping of the inner continental shelf-Nahant to Gloucester, Massachusetts: U.S. Geological Survey Open-File Report 2005-1293. Available online at http://pubs.usgs.gov/of/2005/1293/

Butman, Bradford, Valentine, P.C., Danforth, W.W., Hayes, Laura, Serrett, L.A., and Middleton, T.J., 2004, Shaded relief, backscatter intensity and sea floor topography of Massachusetts Bay and the Stellwagen Bank region, offshore of Boston, Massachusetts: U.S. Geological Survey Geologic Investigations Series Map I-2734, scale 1:125,000, 2 sheets. Available online at http://pubs.usgs.gov/imap/i2734

National Research Council, 2004, A Geospatial Framework for the Coastal Zone-National Needs for Coastal Mapping and Charting, $168 \mathrm{p}$.

Schlee, J. S., 1973, Atlantic continental shelf and slope of the United States-Sediment texture of the northeastern part: U.S. Geological Survey Professional Paper 529-H, 39 p.

U.S. Commission on Ocean Policy, 2004, An Ocean Blueprint for the 21st Century, 676 p.

Zen, E-an, Goldsmith, R., Ratcliffe, N.M., Robinson, P. and Stanley, R.S., 1983, Bedrock geologic map of Massachusetts: U.S. Geological Survey, Washington D.C., scale $1: 250,000,3$ sheets.

\section{For more information contact:}

Walter Barnhardt wbarnhardt@usgs.gov or

Brian Andrews bandrews@usgs.gov

U.S. Geological Survey

Woods Hole Science Center

384 Woods Hole Road

Woods Hole, MA 02543

(508) 548-8700

http://woodshole.er.usgs.gov/project-pages/coastal_mass/ 